\title{
Human rights, responsibilities and the pursuit of a realistic Utopia \\ RichARD MULLENDER*
}

Newcastle Law School, University of Newcastle

\section{Introduction}

$\mathrm{T}$ The chorus line "Things can only get better", which heralded the arrival of New Labour in power, now has a hollow ring. ${ }^{1}$ But, in one area, ministers may still be able to meet the gaze of an increasingly disenchanted public and talk the language of progress. For there can be no doubt that human rights have, in the years since 1997, become an evermore prominent feature of the legal and political landscape. This is a development for which New Labour can claim much of the credit. On entering office, the Blair administration produced a White Paper that spelled out its commitment to weaving human rights into the fabric of municipal law and followed this with the enactment of the Human Rights Act 1998. ${ }^{2}$ The judiciary, legal practitioners and public officials have responded to these developments by taking human rights increasingly seriously in a wide variety of ways. ${ }^{3}$ As a result, talk of human rights has gained currency in the wider culture (much to the annoyance of some commentators). ${ }^{4}$

But some have argued that the Human Rights Act and associated developments have fostered a culture in which an increasing number of rightsholders have lost sight of the legitimate interests of others and the wider community. ${ }^{5}$ In response to this criticism, New

* I am grateful to Robert Colls, Carol Forrest, Andrew Halpin, Aileen Kavanagh, Patrick O'Callaghan, Ole Pedersen and Hillel Steiner for their comments on earlier drafts.

1 During the 1997 general election, “Things can only get better” was New Labour's campaign song. P Toynbee and D Walker, Did Things Get Better? An audit of New Labour's successes and failures (London: Penguin Books 2001), p. 2.

2 Rights Brought Home: The Human Rights Bill, White Paper Cm 3782 (Norwich: The Stationery Office 1997).

3 The developments noted in the text have occurred in public and private law. See, for example, $R \mathrm{v}$ Bow Street Magistrates' Court, exp Pinochet Ugarte (No 3) [2000] 1 AC 447 (where the House of Lords held that a former head of state was liable to be extradited for alleged torture), and J Wright, Tort Law and Human Rights (Oxford: Hart 2001), pp. 21-33 (on the doctrine of indirect horizontal effect and its impact on tort law).

4 See e.g. M Phillips, Londonistan: How Britain is creating a terror state within (London: Gibson Square 2006), ch. 2.

5 The problem with which New Labour is grappling has, on some analyses, been a feature of practical life in the West since (at least) the 1960s. See, for example, F Fukuyama, The Great Disruption: Human nature and the reconstitution of social order (London: Profile Books 1999), p. 10 (on "excessive individualism") and pp. 13-15 (arguing that "a series of liberation movements", dating from the 1960 s, have given expression to a socially damaging "no limits" message). See also J Gray, Gray's Anatomy: Selected writings (London: Allen Lane 2009), pp. 145-6 (arguing that the "antinomian" individualism encouraged by human rights poses a threat to the institutions that sustain a just social order). 
Labour has prepared a Green Paper, Rights and Responsibilities: Developing our constitutional framework in which it canvasses the possibility of enacting a Bill of Rights and Responsibilities. ${ }^{6}$ The Green Paper's authors place emphasis on responsibilities with the aim of identifying ways in which the law can more adequately accommodate the interests of all its addressees. ${ }^{7}$

This is an aspiration that reflects more than the practical agenda of an increasingly unpopular government keen to recommend itself to voters. It gives expression to moral impulses within a culture where, over many centuries, a distinct philosophy of government has (at first naïvely and, at later stages, more self-consciously) grown up. ${ }^{8}$ This is the egalitarian philosophy of government, the central concern of which is to accommodate the interests of all the law's addressees defensibly. This is a philosophy of government that encourages in those who embrace it a reforming outlook that tends towards utopianism. On the analysis offered in this essay, we can find signs of utopianism in New Labour's Green Paper. However, this is not a reason to dismiss it. For John Rawls's account of a "realistic utopia" provides a basis on which to defend Rights and Responsibilities. But, while we can make such a defence, we should, at the same time, be alive to its limits. To this end, we will draw on the political philosophy of Michael Oakeshott and Isaiah Berlin (and the writings of Friedrich Hayek and Milan Kundera). Oakeshott and Berlin have particular relevance to this discussion since they each made anti-utopian contributions to the egalitarian philosophy of government.

\section{Rights and Responsibilities: an overview}

The authors of Rights and Responsibilities offer a number of rationales for a Bill of Rights and Responsibilities. They state that "people need to feel secure" in "turbulent times" and argue that increased emphasis on responsibilities may be warranted since human rights-based protections have, on some analyses, encouraged "selfish individualism".? While these rationales are responses to a current practical concern ("turbulent times") and a debate (concerning the possibility that rights may foster selfishness), others give expression to the agenda New Labour has pursued since 1997. This becomes clear when the authors state that increased emphasis on responsibilities affords a means by which to "strengthen communities" and address "the ... constitutional question of the relationship between the citizen and the state". ${ }^{10}$ For these reasons, they go on to describe Rights and Responsibilities as intended to advance New Labour's "progressive" agenda. ${ }^{11}$

6 Rights and Responsibilities: Developing our constitutional framework, Green Paper Cm 7577 (London: Ministry of Justice 2009) (hereinafter RR).

7 RR is the work of the Ministry of Justice. Hence, it reflects the thinking of the Secretary of State for Justice, Jack Straw, and those who have worked with him on its preparation (including Michael Wills MP). For this reason, this essay refers to "the authors" of RR. This locution points up the fact that we are dealing with a distinct contribution to the contested New Labour project. See also P Wintour, "Straw hails new rights to end the 'me' society", The Guardian, 24 March 2009, p. 6.

8 The phrase "philosophy of government" is taken from H L A Hart, Essays in Jurisprudence and Philosophy (Oxford: OUP 1983), p. 198.

9 RR, p. 3 (associating "turbulent times" with "a . . crisis in the world's financial system") and p. 17. See also P Eleftheriadis, "On rights and responsibilities" (2010) Public Law 33, at 33-8 (identifying the "core argument" in Rights and Responsibilities as comprising three steps: by encouraging selfish individualism, rights exhibit a "moral flaw"; for this reason, they "threaten[] social cohesion and community"; hence, "rights ought to be publicly linked to responsibilities").

10 RR, p. 3.

11 RR, p. 3. 
This agenda, as the "Foreword" to Rights and Responsibilities makes plain, has many elements. They include the Equality Bill, the Welfare Reform Bill and the pledge to eradicate child poverty by $2020 .{ }^{12}$ Alongside these measures, the government wishes to explore the possibility as to whether "responsibilities can be given greater resonance" alongside the rights protected by the Human Rights Act. ${ }^{13}$ On this topic, the authors take the view that a Bill of Rights and Responsibilities would have "great symbolic and cultural importance" and could (along with, inter alia, the welfare state) become a landmark of the constitution. ${ }^{14}$ While sounding this ambitious note, they also state that the government's aim is not to "draw [] up blueprints for new [social] models" or to meet the requirements of "an abstract system of ideals". 15 Rather, it is to explore the possibility of cautious constitutional change (on a model that has long been a feature of politico-legal life in Britain). ${ }^{16}$

Before turning to the topic that is their central concern (responsibilities), the authors dedicate a chapter to bills of rights. They seek, among other things, to place New Labour's human rights-related agenda in historical and global context. They find in, inter alia, the Magna Carta 1215 and the Declaration of Arbroath 1320 "proud traditions of liberty". 17 Moreover, they set New Labour's innovations and plans in the context of the human rights revolution that has been unfolding since the end of World War Two. ${ }^{18}$ To this end, they situate the Human Rights Act in the context of a process of politico-legal development embracing the Universal Declaration of Human Rights and regional and municipal human rights instruments. ${ }^{19}$ They also identify New Labour's human rights-related agenda as part of a process of development that embraces the US Constitution and Bill of Rights and the French Declaration of the Rights of Man and of the Citizen. ${ }^{20}$

Rights and Responsibilities does not, however, focus narrowly on human rights. The authors also seek to point up the practical significance of welfare provision in Britain in the twentieth and twenty-first centuries. Thus, we find them discussing, among other things, the National Health Service. ${ }^{21}$ Moreover, they dwell on the relationship between human rights and welfare as components in an egalitarian politico-legal project. They illustrate this relationship by reference to South Africa's Bill of Rights 1996. This instrument guarantees "not only . . . traditional civil and political rights, but also social and economic [entitlements]".22 In fastening on this feature of South African law, the authors alert us to a theme that features in their thinking. This is the desirability of seeing human rights, welfare provision and "the delivery of key public services" (e.g. the protection provided by the criminal justice system) as components in a progressive political agenda. ${ }^{23}$

Even before they have reached the end of their chapter on bills of rights, the authors have turned to the topic that is their central concern: whether "the articulation of
12 RR, p. 3.
13 RR, p. 8.
14 RR, p. 8.
15 RR, p. 7.
16 RR, p. 7.
17 RR, p. 12 (1.11).
18 RR, p. 12 (1.9). See also M Ignatieff, "Human rights as politics" in A Gutmann (ed.), Human Rights as Politics and Idolatry (Princeton: Princeton UP 2001), pp. 5-6 (on the post-World War Two human rights revolution).
19 RR, pp. 11-12.
20 RR, p. 11 (1.3-4).
21 RR, p. 12 (1.11).
22 RR, p. 11 (1.6).
23 RR, pp. 10, 11 (1.6) and 32-7 (3.15-31). 
responsibilities" would enhance Britain's "constitutional arrangements". ${ }^{24}$ This leads (in their chapter on responsibilities) to a rather breathless account of the notion of "individual responsibility". They tell us that individual responsibility is "a time-honoured concept for healthy and vibrant societies". 25 The authors find support for this claim in ancient Greece and Rome where "philosophers ... stressed that individual responsibility is an essential ingredient for the well-being and flourishing of a community and its members". 26 This appeal to the classical world betrays no sensitivity to the point that contemporary understandings of individuality, personal responsibility and community differ from those in Greece and Rome. ${ }^{27}$ The upshot is an anachronistic analysis that would not win plaudits from those (e.g. Quentin Skinner) who dwell on the evolution of politically significant ideas. ${ }^{28}$

The obvious explanation for this feature of Rights and Responsibilities is that the authors are using the past as grist to their argumentative mill. A further feature of their brisk journey through Western history lends force to this explanation. They find not just in ancient Greece and Rome but also in the philosophy that inspired the American and French revolutions support for the proposition that "responsibilities" play a "critical role" in "fostering a peaceful and harmonious society". 29 They also find support for this proposition in the communitarian political philosophy of Amitai Etzioni and Mary Ann Glendon. ${ }^{30}$ Moreover, the authors forge a link between this body of political philosophy (within which they identify a strong commitment to "civic virtue") and socialism. ${ }^{31}$ For socialism is, they tell us, associated with "co-operative action". 32 The authors make clear what they mean by "co-operative action" by adding that it has to do with balancing "the individual and community interest". 33 The importance they attach to this point becomes clear when they turn to the context in which they are writing. They state that this context is "more atomised" than in the past. ${ }^{34}$ The authors also draw on comment running on the theme that "an overemphasis on rights, to the exclusion of notions of responsibility, can lead to a 'me' society rather than a "we' society". 35 This, they add, threatens to harm the "philosophical basis of inalienable, fundamental human rights and public support for them". 36

Having sought to point up the practical significance of responsibilities, the authors consider how government might give them suitable emphasis in a rights-respecting constitutional order. They state that " $t]$ he Government is clear" on the point that

24 RR, pp. 13 (1.16) and $5(\mathrm{xv})$.

25 RR, p. 15.

26 RR, p. 14 (2.2).

27 See M Schofield, Plato (Oxford: OUP 2006), pp. 219-20 (on the "organic" conception of social life in the classical world), and A MacIntyre, A Short History of Ethics (London: Routledge 2002), p. 192 (on communities, from the eighteenth century onwards, as "collections of individuals").

28 K Palonen, Quentin Skinner: History, politics, rhetoric (Cambridge: Polity Press 2003), pp. 20, 39 and 52 (on constant conceptual change as a feature of politically significant ideas).

29 RR, p. 14 (2.5).

30 RR, p. 15 (2.7 and note 6).

31 RR, p. 15 (2.7-8).

32 RR, p. 15 (2.8).

33 RR, p. 15 (2.10).

34 RR, p. 17 (2.15).

35 RR, p. 17 (2.17).

36 RR, p. 17 (2.18). 
"fundamental rights cannot be legally contingent on the exercise of responsibilities". ${ }^{37}$ But what follows in Rights and Responsibilities is less clear. The authors state that it may be possible to give responsibilities "greater resonance in a manner which does not necessarily link them to the adjudication of particular rights". 38 They follow this with an examination of international and national instruments that recognise the importance of responsibility in social contexts informed by a strong commitment to justice ${ }^{39}$ These instruments include the Universal Declaration of Human Rights, the preamble to the Australian Capital Territory's Human Rights Act 2004 and the Polish Constitution. ${ }^{40}$ The authors identify these instruments as sharing two closely related themes: those who enjoy the protection of rights should seek to "foster ... shared values" and act in ways that show "concern for the common good". ${ }^{41}$ Moreover, the authors link this practical outlook with ideas of duty, citizenship and community. ${ }^{42}$ Rights and Responsibilities does not explore the relationship between these ideas with any degree of precision. But they each clearly have to do with the pursuit of a goal that bulks large in the minds of the authors: this is to continue "build[ing] a secure and flourishing society". 43

The authors follow this examination of responsibilities with a chapter on rights that begins unpromisingly. For they sound another anachronistic note when they claim that " $[\mathrm{t}]$ hroughout history, philosophers have articulated theories of a society governed by law and ... the rights which individuals consequently possess". 44 This claim appears to give expression to the assumption that individual rights have been a constant feature of the historical contexts that the authors survey. If they do make this assumption, they are wrong. The term "right" has not been a permanent feature of the Western politico-legal landscape. ${ }^{45}$ Before rights talk gained currency, the notion of ius did broadly similar but less individualistic work (by focusing on the question as to what is "fair" between the members of a community). ${ }^{46}$ Moreover, since the emergence of the notion of a human right in a naïve form, political, moral and legal commentators have refined our understanding of it. ${ }^{47}$ The breezy insensitivity to these points on display in Rights and Responsibilities reveals the

37 RR, p. 18 (2.22). Cf. A Giddens, The Third Way: The renewal of social democracy (Cambridge: Polity Press 1998), p. 65 (arguing that "no rights without responsibilities" could be "a prime motto" of the "third way" political agenda embraced by New Labour). While Giddens may be correct on this point, Neil Kinnock forged the same sort of link between rights and responsibilities when he declared (while addressing the Welsh Labour Party in 1987): "we co-ordinate so that everyone can contribute and everyone can benefit, everyone has responsibilities, everyone has rights". See P Kellner, Democracy: 1,000 years in pursuit of British liberty (Edinburgh: Mainstream Publishing 2009), p. 481.

38 RR, p. 18 (2.22).

39 RR, p. $22 \mathrm{ff}$.

40 RR, p. 22 (2.40-3) and 26 (2.57 and 2.60). See also p. 24 (2.47-8) (on the duties to serve the community enunciated in the American Declaration of the Rights and Duties of Man (1948)).

41 RR, pp. 26 (2.60) (quoting from the Polish constitution) and 28 (2.66).

42 RR, pp. 24 (2.48) and 27 (2.62).

43 RR, p. 19 (2.27).

44 RR, p. 29 (3.1).

45 M Freeden, Rights (Milton Keynes: Open UP 1991), p. 26 (noting that "historically the concepts of law and duty ... preceded that of rights"). See also J M Finnis, Natural Law and Natural Rights (Oxford: Clarendon Press 1980), p. 210.

46 Finnis, Natural Law, n. 45 above, p. 206, contrasting individual rights with ius. On Finnis's (Aquinasinfluenced) account, ius is captured by the noun "arights": i.e. fair arrangements between the members of a community. See also J Griffin, On Human Rights (Oxford: OUP 2008), pp. 1 and 31.

47 See, for example, R Dworkin, Taking Rights Seriously (London: Duckworth 1977), pp. 190-1 (on the right to free expression as a "trump" vis-à-vis a wide range of arguments having to do with the public interest). See also Griffin, On Human Rights, n. 46 above, pp. 1 and 30-2 (tracing the emergence of the idea of a human right to the late Middle Ages). 
same lack of subtlety when dealing with relevant history that we found in the authors' references to the classical world.

Rights and Responsibilities also exhibits a strong tendency to elide human rights (a distinct form of "strong protection") with other goods that serve to underwrite a just (or, at least, well governed) social order. ${ }^{48}$ This tendency is plain to see when the authors turn to the emergence of the British welfare state. They note that "[s]ome 20th-century theorists . . . began to take an increasingly comprehensive view of rights". 49 This, they tell us, is true of T H Marshall who identified three types of rights (civil, political and social) as associated with "full membership in the community" (or citizenship). ${ }^{50}$ The authors endorse this view. This is anything but surprising, for their central concern is to establish a framework that defensibly accommodates the interests of all those who live within it. ${ }^{51}$ On this view, human rights are part of a larger whole (including welfare provision and public goods such as an ordered and respectful environment) that serves the end of distributive justice. ${ }^{52}$ In light of this point, we have a basis on which to explain why responsibilities have become a pressing concern. Fearful that some rightsholders are attaching undue importance to their own interests, government now wishes to establish "a link between rights and responsibilities". 53 This "link" is the idea of balancing interests and, at a foundational level, the ideal of distributive justice.

The government's commitment to balancing interests is a point to which the authors return on many occasions. ${ }^{54}$ In their chapter on rights, they refer to the "balancing provisions" of the Human Rights Act and the European Convention on Human Rights. ${ }^{55}$ Here, they are referring to the proportionality principle (which affords a means by which to address the problems that arise when "individual and societal interests collide"). ${ }^{56}$ This principle specifies that government and public bodies should only override the interests of individuals where doing so is necessary in order to pursue an outcome that serves the public interest. ${ }^{57}$ While the authors (in common with many judges and commentators) refer to proportionality as a "balancing" principle, it is far from obvious that it does the sort of work suggested by this term. For "balancing" suggests that those using the principle are able to weigh all relevant concerns on the same set of scales. This is a point to which we will return below.

While confident that government can balance interests justly, the authors are less surefooted in their penultimate chapter, which concerns a crucial question of institutional design. This is how to make responsibilities a more prominent feature of the politico-legal landscape. The authors state that "[t]he possible range of approaches to a Bill of Rights and

48 RR, pp. 42 (3.51) (on employment-related training and "minimum standards in public services") and 44 (3.56) (on housing). On human rights as a distinct form of "strong protection", see J Griffin, On Human Rights, n. 46 above, p. 90.

49 RR, p. 30 (3.5).

50 RR, p. 30 (3.5), referring to T H Marshall, Citizenship and Social Class (Cambridge: CUP 1950), p. 6.

51 See, for example, RR, p. 57 (4.25) (on "fair provision for society as a whole").

52 Distributive justice has to do with establishing a fair allocation of benefits and burdens in society (or within some socially significant institutions). See J Rawls, A Theory of Justice (Oxford: OUP 1971), p. 4. See also J Raz, The Morality of Freedom (Oxford: Clarendon Press 1986), p. 199 (on the public good of an environment "infused with a sense of respect for human beings").

53 RR, p. 8.

54 RR, pp. 4 (vi), 5 (xi), 9, 15 (2.10), 25 (2.53), 29 (3.4), 30 (3.7), 49 (3.78) and 55 (4.19).

55 RR, p. 30 (3.7).

56 RR, pp. 55 (4.19) (where the authors identify the proportionality principle as the balancing provision to which they are making reference) and 31 (3.9).

57 D Pannick, "Principles of interpretation and Convention rights under the Human Rights Act and the discretionary area of judgment" (1998) Public Law 545, at 547-8. 
Responsibilities represents a continuum".58 At one end of this continuum lies "a declaratory or symbolic statement" while, at the other, we find "a set of rights and responsibilities directly enforceable by the individual in the courts". 59 The authors are clearly uneasy about the second of these approaches. This is because it would, on their account, increase the likelihood that the courts would assume "a more important role in protecting individual freedoms". ${ }^{60}$ For this reason, they dwell on an approach that lies in the middle of the spectrum they describe. This is a general interpretative provision. ${ }^{61}$ According to the authors, such a provision would provide legislators and courts with guidance on the question as to how they should weave a suitably strong commitment to responsibilities into the fabric of the law. ${ }^{62}$

While considering how to develop Britain's constitutional framework in a way that will give greater prominence to responsibilities, the authors consider two further matters. They recognise that a process of development of the sort they contemplate will raise controversial questions concerning resource allocation. On this point, they state that such questions are a matter for Parliament. ${ }^{63}$ Moreover, they tell us that "it is the Government's clear view that Parliamentary sovereignty must remain as the cornerstone of the UK constitution". ${ }^{64}$ The authors also recognise that government will have to make clear the relationship between a Bill of Rights and Responsibilities and other human rights-related provisions. Before drawing this chapter to a close, they also introduce a further (egalitarian) rationale for reform. By placing greater emphasis on responsibilities, the government will take a step towards ensuring that "everyone has a fair chance to participate in society" ${ }^{65}$ In their brief concluding chapter, the authors add only one point of significance. This is that a Bill of Rights and Responsibilities should reflect a "broad consensus" on values. ${ }^{66}$ The government might find a basis on which to establish this consensus in the philosophy of government to which we now turn.

\section{The egalitarian philosophy of government}

We can trace the roots of this philosophy of government back to Europe in the late Middle Ages. At this time, the view that "important powers and privileges . . . were simply to be derived from one's human status" began to gain currency. ${ }^{67}$ By the seventeenth century, we find Hobbes, while arguing for the Leviathan state, identifying all men as having an equal interest in peace. ${ }^{68}$ This egalitarian strand in Hobbes's thinking made a great impression on Kant who, in the eighteenth century, offered a more robust variation on the same theme. According to Kant, a state only deserved the description "good" if it established a body of law that defensibly accommodated the interests of all its citizens. ${ }^{69}$ Where states met this requirement, they acted, on Kant's account, in conformity with the universal principle of

58 RR, p. 52 (4.2).

59 RR, p. 52 (4.2).

60 RR, p. 51 (4.3).

61 RR, pp. 55-6 (4.18-23).

62 RR, p. 55 (4.18-20).

63 RR, p. 57 (4.27).

64 RR, p. 57 (4.27).

65 RR, p. 60 (4.39).

66 RR, p. 62 (5.1). The government recognised the need for a broad consensus in its earlier Green Paper, The Governance of Britain Cm 1770 (Norwich: HMSO 2007), p. 63, para. 213.

67 Griffin, On Human Rights, n. 46 above, p. 40.

68 T Hobbes, Leviathan, R Tuck (ed.) (Cambridge: CUP 1991), p. 92.

69 R J Sullivan, An Introduction to Kant's Ethics (Cambridge: CUP 1994), pp. 11-12. 
justice. This principle is highly relevant to this discussion. This is because it points up a relationship (in the egalitarian philosophy of government) between the state, law and the citizen that Britons and Westerners more generally now take for granted. This relationship is one in which law and the state underwrite a conception of the individual as a source of intrinsic value.

While this conception of the individual runs like a connecting thread through the history of the egalitarian philosophy of government, this body of thought has developed constantly since its emergence. The philosopher Charles Taylor has traced this process of development. He identifies Hobbes and Kant, along with, inter alios, Grotius, Pufendorf, Locke, Rousseau and Hegel, as having played prominent roles in establishing a new "moral order". 70 Moreover, this "moral order" (or, as we have styled it here, "philosophy of government") has gone through a number of "redactions". ${ }^{71}$ Taylor also claims that each of these redactions has been "more demanding" than the previous one. ${ }^{72}$ There is something in this. In Hobbes, we find an emphasis on freedom from interference (or negative liberty) as an interest that people have in common. But some later contributors to the egalitarian philosophy of government (e.g. Jean-Jacques Rousseau) place emphasis on a more complex notion of freedom. This notion embraces a range of interests (over and above non-interference) that make it possible for people to live freely (e.g. by leading a life of authentic self-direction). ${ }^{73}$ Proponents of this view also argue that people grasp these interests more or less adequately. In light of these points, they conclude that the state should act in ways that enable (or perhaps even force) individuals to live lives that more adequately approximate the ideal of freedom. This view of freedom, like that propounded by Hobbes, is intensely controversial. Critics of the Hobbesian view may argue that it underwrites a night-watchman state that will be unable to deliver the goods necessary in order for those who live within it to flourish. ${ }^{74}$ By contrast, those who criticise the more ambitious (Rousseauian) view argue that it entails a state that tends in an authoritarian direction. ${ }^{75}$

Disagreement concerning the state's proper role is only one of many areas in which those who embrace either modest or more ambitious versions of the egalitarian philosophy of government disagree with one another. A related source of disagreement concerns rights. Those who cleave to the modest view associate rights with protection from other individuals and government. Thus, they might characterise the human right to free expression as a "protective capsule" that insulates individuals from the claims of those around them. ${ }^{76}$ Matters are significantly different when we turn to more ambitious understandings of the egalitarian philosophy of government. Those who make contributions to this body of thought place emphasis on positive claim rights: for example, entitlements to goods that facilitate the pursuit of a fulfilling life. ${ }^{77}$ To stake out positions of this sort is to argue for or presuppose an extensive state apparatus that proponents of the more modest view typically regard as posing a threat to the freedom of individuals. While disagreements of this type rumble on interminably, those who participate in them agree on one point concerning rights: they are a particularly powerful symbol of the egalitarian philosophy to which they give expression. This is a point that Ronald Dworkin has repeatedly driven home. He argues

70 C Taylor, A Secular Age (Cambridge, Mass: Harvard UP 2007), ch. 4.

71 Ibid., p. 160.

72 Ibid.

73 G Crowder, Isaiah Berlin: Liberty and pluralism (Cambridge: Polity Press 2004), p. 67.

74 Rawls, $A$ Theory, n. 52 above, p. 205.

75 Crowder, Isaiah Berlin, n. 73 above, ch. 3.

76 Freeden, Rights, n. 45 above, p. 7.

77 Raz, Morality, n. 52 above, p. 415. 
that the rights-based protections enjoyed by individuals in the United States and Britain give expression to an abstract egalitarian principle. This principle specifies that the state must treat its citizens with equal concern and respect. ${ }^{78}$

While rights have bulked large in the egalitarian philosophy of government, other considerations (such as the provision of welfare) also occupy a place of prominence within it. ${ }^{79}$ Moreover, the precise idiom in which proponents of this philosophy talk typically reflects the culture and historical epoch in which they seek to have a practical impact. We can illustrate this point by reference to Britain between the second half of the nineteenth century and the middle of the twentieth century. During this period, the Fabians and New Liberals identified state intervention (in spheres such as education) as a means by which to secure the interests of society's poorer members. ${ }^{80}$ In the course of advancing their arguments, they placed emphasis not on rights but, rather, on welfare. For they saw in this broad notion a means by which to pursue a just end-state (characterised as, among other things, New Jerusalem). But, by the middle of the twentieth century, we can detect an increasing emphasis on rights as a means to the same end.

Shifts of this sort are (as Charles Taylor notes) a prominent feature of the body of thought we are surveying. However, some of its features have remained stable over time. It has, at all times, been progressive. Those who have embraced this philosophy have seen in it a basis on which to establish increasingly adequate sets of practical arrangements. Thus, they have regarded themselves as probing the limits of practicable political possibility. This point merits emphasis. For, on the analysis offered by John Rawls, those who take this view express a commitment to the pursuit of a "realistic utopia". ${ }^{81}$ Moreover, Rawls has identified the idea of a realistic Utopia (as it applies "[i]n the domestic [or municipal] case") as "importantly institutional". 82 By this he means that "it connects with the way citizens conduct themselves under the practices and institutions" that order their lives. ${ }^{83}$ But while his account of a realistic Utopia has this institutional focus, Rawls is at pains to point out that it takes people as they are. ${ }^{84}$ These points have, as we will see, great relevance to Rights and Responsibilities (and New Labour's agenda more generally).

\section{New Labour and the pursuit of a realistic Utopia}

Rawls's notion of a realistic Utopia is relevant not just to New Labour but to the political tradition (British and more generally Western) of which it is a part. We can find in British political history a readiness (sustained over many centuries) to probe the bounds of political

78 R Dworkin, Law's Empire (London: Fontana Press 1986), pp. 222 and 296. See also Dworkin, Taking Rights Seriously, n. 47 above, pp. 272-8.

79 See T H Marshall, Social Policy in the 20th Century 4th edn (London: Hutchinson 1975) (tracing the development of welfare policy in Britain from 1890).

80 M Loughlin, Public Law and Political Theory (Oxford: Clarendon Press 1992), pp. 116-23, and B Wilson, What Price Liberty? How freedom was won and is being lost (London: Faber \& Faber 2009), ch. 8.

81 J Rawls, Lectures on the History of Political Philosophy (Cambridge, Mass: Harvard UP 2007), pp. 10-11. In talking of a "realistic utopia", Rawls makes it plain that he has in mind something significantly different from a Utopia. But Charles Taylor provides grounds for thinking that the (Rawlsian) realistic Utopia/Utopia distinction may be too sharp. He argues that the notion of Utopia gives expression to the belief that "these things are really possible in the sense that they lie in the bent of human nature". See C Taylor, A Secular Age, n. 70 above, p. 785 , note 15.

82 J Rawls, The Law of Peoples (Cambridge, Mass: Harvard UP 2001), p. 16.

83 Ibid.

84 Ibid., pp. 12-13. 
possibility. ${ }^{85}$ We see it in the emergence and extension of the democratic principle. ${ }^{86}$ Likewise, we see it in the increasing emphasis given to freedom of expression and the associated ideal of toleration. ${ }^{87}$ But when we focus on British political history in the latter part of the nineteenth century, talk of utopianism (as Rawls employs that term) becomes particularly relevant. For we find in the writings of the Fabians and the New Liberals a common theme: the desirability of pursuing (by welfarist means) an end-state in which all Britons would live secure, dignified lives. ${ }^{88}$ Moreover, when we survey the history of the welfare state in twentieth-century Britain, we find that those who followed in the footsteps of these thinkers sought to make the end-state that they argued for a reality. It is in this context (oriented towards the pursuit of a welfarist New Jerusalem) that we find $\mathrm{T} \mathrm{H}$ Marshall setting out his account of civil, political and social rights. ${ }^{89}$ Marshall is a pivotal figure in this process of development. ${ }^{90}$ For one of his contributions to the body of thought we are surveying was to encourage a shift in the idiom of its proponents. He did this by giving emphasis to "rights" rather than to "welfare". 91 Marshall was not alone in encouraging this change. Those who spent the war years arguing for human rights played a significant part in bringing this change about. ${ }^{92}$

We might see the shift (from welfare to rights) encouraged by, inter alios, Marshall as an instance of modest progress in the direction of a more attractive model of human association. However, within the body of welfarist thought that Marshall played a part in elaborating, progress is associated with an ambitious (or progressive) state that plans for a better future and designs institutions that will make it a reality. This view of the state gives expression to a large assumption: those who wield the levers of power can fashion institutions that accommodate all relevant interests harmoniously. We find this assumption in Rights and Responsibilities and the New Labour agenda more generally. ${ }^{93}$ However, this assumption is, for reasons explored below, highly questionable.

85 Kellner, Democracy, n. 37 above, pp. 24-33. See also R Mullender, "Democracy in the Land of Good Things (Britain)" (2010) 81 Political Quarterly 146.

86 C Turpin and A Tomkins, British Government and Constitution 6th edn (Cambridge: CUP 2007), pp. 34-40.

87 See E Barendt, Freedom of Speech 2nd edn (Oxford: OUP 2005), pp. 39-48; Wilson, What Price Liberty?, n. 80 above, p. 158, and N Ferguson, The War of the World: History's age of hatred (London: Allen Lane 2006), p. 626.

88 Loughlin, Public Law, n. 80 above, pp. 116-23, and M Oakeshott, The Vocabulary of the Modern European State, L O’Sullivan (ed.) (Exeter: Imprint-Academic 2008), ch. 39.

89 See A Vincent and R Plant, Philosophy, Politics and Citizenship: The life and thought of the British idealists (Oxford: Basil Blackwell 1984); C Barnett, The Lost Victory: British dreams, British realities 1945-50 (London: Macmillan 1995), p. 123; and P Hennessey, Never Again: Britain 1945-51 (London: Penguin Books 2006), ch. 4, pp. 180 and 324 .

90 On Marshall's “seminal” contribution to the body of thought we are considering, see S Fredman, Human Rights Transformed: Positive rights and positive duties (Oxford: OUP 2008), p. 227.

91 D Marquand, The Unprincipled Society: New demands and old politics (London: Fontana Press 1988), pp. 28-9 (noting that social rights on the model argued for by Marshall became part of the welfare "strand" of Keynesian social democracy after World War Two: the change in idiom noted in the text was, on Marshall's analysis, due to improved material circumstances ( $\mathrm{T}$ H Marshall, Class, Citizenship and Social Development (Westport, Connecticut: Greenwood Press 1973), p. 104)).

92 Griffin, On Human Rights, n. 46 above, pp. 176-7.

93 See Discrimination Law Review: A framework for fairness: proposals for a single equality bill for Great Britain (London: Department for Communities and Local Government 2007), p. 9 (on “joined up action across government" with the aim of promoting "fairness and social justice" in, inter alia, the fields of equality for ethnic minorities, disability, and domestic violence). See also T Clark, "New Labour's big idea: joined-up government” (2002) 1 Social Policy and Society 107. 


\section{Hubris and the "grand march"}

If the analysis in the last section is correct, the authors of Rights and Responsibilities are seeking to offer a solution to problems associated with the protection of fundamental rights that is utopian in thrust. In following others in the progressive British tradition of which the Labour Party is a part in adopting this approach, they expose themselves to some criticisms that Friedrich Hayek levelled at some of their predecessors. Hayek identified the welfarist agenda that gained currency in Britain as the Second World War neared its end as a threat to the liberty of individuals. ${ }^{94} \mathrm{He}$ also drew attention to an assumption that, on his analysis, informed the thinking of ministers and officials at this time. This is the assumption that they had sufficient knowledge to draw up a "comprehensive plan" for the effective pursuit of "social justice". 95 Hayek regarded those who made this assumption as exhibiting hubris (and an associated tendency towards authoritarianism). ${ }^{96}$

In the 1980s, these features of Hayekian political philosophy found an echo in the work of the novelist Milan Kundera. In The Unbearable Lightness of Being, Kundera argued that those who embrace the cause of progressive, egalitarian politics see themselves as participating in a "grand march . . . on the road to brotherhood, equality, [and] justice". 97 On Kundera's account, this march, while giving expression to noble aspirations, has malign effects. ${ }^{98}$ This is because those who lead the march are apt to treat (or, at least, regard) those who follow them as mere means to an egalitarian end (rather than as ends in themselves). ${ }^{99}$ Kundera adds that those who behave in this way often seek to deny that they are doing so. To this end, they present the society in which they wield the levers of power as a "smiling brotherhood". 100 This is a model of human association that is harmonious since all those who live within it focus on and find fulfillment in the pursuit of justice. On Kundera's analysis, this representation of the situation he describes is bogus. He seeks to capture its dishonesty by categorising it as an example of kitsch. By this he means that it is a representation that offers a sanitised account of life: that is an account that does not acknowledge the practical difficulties with which people must wrestle. ${ }^{101}$

Both Hayek and Kundera make points that are relevant to Rights and Responsibilities. The authors of this Green Paper use a metaphor that tells of their self-understanding as social architects. For they state that their aim is to reconfigure the nation's "constitutional architecture". 102 This looks very much like the mindset that drew criticism from Hayek. ${ }^{103}$

94 F A Hayek, The Road to Serfdom (London: Routledge 1944). Hayek pursued the same theme in F A Hayek, The Constitution of Liberty (London: Routledge 2006), pp. 225-6. See also R Colls, Identity of England (Oxford: OUP 2002), pp. 84, 130 (on progressive political opinion in the 1940s) and 373 (on Hayek).

95 Hayek, The Constitution, n. 94 above, p. 222.

96 Ibid., pp. 37 and 226-7. The themes pursued by Hayek were also present in mainstream political discourse in the 1940s. See D Kynaston, Austerity Britain (London: Bloomsbury 2007), pp. 58, 201, 227-8, 431 and 525.

97 M Kundera, The Unbearable Lightness of Being (London: Faber \& Faber 1985), p. 250. Charles Taylor offers a broader variation on Kundera's theme of the grand march. He describes egalitarian thought from the seventeenth century onwards as "the long march". See C Taylor, Modern Social Imaginaries (Durham: Duke UP 2004), p. 30.

98 Kundera, Unbearable Lightness, n. 97 above, pp. 239-50.

99 Ibid., pp. 244-5.

100 Ibid., p. 250.

101 Ibid., p. $241 \mathrm{ff}$. See also P Roth, The Human Stain (London: Vintage 2001), p. 242 (on "the quest to purify" social relations as "more impurity").

102 RR, p. 17 (2.16). See also p. 58 (where the authors identify themselves as concerned with "governance arrangements").

103 See Hayek, The Road, n. 94 above, p. 20 (associating the "habits of thought" of those who pursue the welfarist (and more generally statist) agenda, he criticises with "the engineer" and "the natural scientist"). 
Moreover, the authors' emphasis on community and consensus conveys the impression that harmony (if not a smiling brotherhood) is a live possibility. ${ }^{104}$ These are points that we can develop by drawing on the writings of Michael Oakeshott and Isaiah Berlin.

\section{The anti-utopianism of Isaiah Berlin and Michael Oakeshott}

\section{(A) OAKESHOTT}

Oakeshott draws a distinction between two models of human association each of which has relevance to this discussion. He labels the first of these models "enterprise association" and tells us that it is highly instrumental. ${ }^{105}$ Those who govern an enterprise association organise it with the aim of pursuing a desired goal or end-state. This may be, for example, a set of social relations that is distributively just. ${ }^{106}$ While the pursuit of such an end-state may lend an enterprise association moral appeal, Oakeshott is critical of this approach to governance since, on his analysis, it compromises individualism. ${ }^{107}$ This is because those who govern an enterprise association treat the end-state they pursue as their primary concern and are apt to regard the individuals over whom they wield power as means to its pursuit. ${ }^{108}$

This is not, on Oakeshott's account, a problem in the second model of human association he describes: "civil association". He tells us that a civil association, unlike an enterprise association, is not concerned with "plans for imposing substantive activities".109 Rather, it constitutes a modest, rule-governed, politico-legal framework. Oakeshott describes this framework (with some awkwardness) as non-instrumental. By this he means that those who live within a civil association may "pursue the activities of their own choice with the minimum of frustration". 110 The "minimum" to which Oakeshott refers is a readiness on the part of individuals to act in accordance with the "general rules of conduct" that constitute and sustain the framework. ${ }^{111}$ While exhibiting a clear preference for civil association, Oakeshott recognises that the Western political tradition is informed by commitments to both of the models that he describes. 112 Consequently, the "modern European state" exhibits, on Oakeshott's analysis, an equivocal character. ${ }^{113}$

Oakeshott's distinction between enterprise and civil association enables us to gain analytic purchase on Rights and Responsibilities and New Labour's human rights-related agenda

104 While New Labour politicians do not invoke the idea of "brotherhood", it was invoked in the early 1950s by Michael Young (who bore primary responsibility for drafting Labour's manifesto for the 1945 general election). See Kynaston, Austerity, n. 96 above, pp. 539-40.

105 M Oakeshott, On History and Other Essays (Oxford: Basil Blackwell 1983), p. 153, and M Oakeshott, On Human Conduct (Oxford: Clarendon Press 1975), pp. 289 and 315.

106 There is no necessary relationship between enterprise association and egalitarianism. See R Mullender, "Nazi law and the concept of community" (2008) 58 University of Toronto LJ 377, at 381-2.

107 Oakeshott, On Human Conduct, n. 105 above, pp. 115, 119, 157-8, 206, 264, 298, 315-17 and 319. See also P Franco, Michael Oakeshott: An introduction (New Haven: Yale UP 2004), p. 170.

108 Oakeshott, On Human Conduct, n. 105 above, p. 273. See also J-J Rousseau, The Social Contract and Discourses, G D H Cole (trans.) (London: Everyman's Library 1973), bk II, ch. 4.

109 M Oakeshott, "On being Conservative", in Rationalism in Politics and Other Essays (London: Methuen, 1977), p. 183.

110 Ibid. See also M Oakeshott, On Human Conduct, n. 105 above, p. 243 (describing a civil association as "the civitas peregrina: an association, not of pilgrims travelling to a common destination, but of adventurers each responding as best he can to the ordeal of consciousness in a world composed of others of his kind").

111 Oakeshott, “On being Conservative”, n. 109 above, p. 183. See also Franco, Michael Oakeshott, n. 107 above, p. 161, on "standards of civility".

112 On Oakeshott's preference for civil association, see Franco, Michael Oakeshott, n. 107 above, pp. 164-70.

113 Oakeshott, On Human Conduct, n 105 above, ch. 4. See also Franco, Michael Oakeshott, n. 107 above, pp. $164 \mathrm{ff}$. 
more generally. Some passages in Rights and Responsibilities make glancing references to ideas that Oakeshott associates with civil association (e.g. negative freedom). ${ }^{114}$ But the authors' central concern reveals them to be proponents of enterprise association. They dwell on the means by which to pursue an end-state in which all the law's addressees enjoy access to the goods necessary in order to flourish. Moreover, Rights and Responsibilities emphasises the role played by the law's addressees in the pursuit of this end-state. By behaving responsibly, they will secure the interests of others and facilitate pursuit of the government's distributive justice-related plans. ${ }^{115}$ We can present human association on this model in a very attractive light. We might, for example, describe those who conduct themselves in the way outlined here as acting in accordance with a personal virtue of justice (by playing their part in a co-operative scheme). ${ }^{116}$ Moreover, we might describe this approach to practical life as giving content to the idea of "community" as it features in Rights and Responsibilities and New Labour's thinking more generally. But Oakeshott would, doubtless, tell a different story. $\mathrm{He}$ would describe the model of human association we are contemplating not as a community but, rather, as an enterprise association in which people begin to take on the appearance of pieces in a social jigsaw. Moreover, he would find support for this view in the emphasis that Rights and Responsibilities places on "a 'we' society rather than a 'me' society". 117 For, on Oakeshott's analysis, language of this sort portends a threat to the idea of individualism. ${ }^{118}$

\section{(B) BERLIN}

While Oakeshott encourages us to think about the shape that egalitarian models of human association might assume, Berlin prompts us to consider a number of concepts that have relevance to them. Prominent among these concepts is "liberty" or "freedom". 119 Berlin famously distinguished between two "senses" of liberty or freedom - one "negative" and the other "positive". 120 Negative liberty features in the writings of many prominent contributors to the egalitarian philosophy of government, including Thomas Hobbes. ${ }^{121}$ Liberty on this model is the absence of coercive interference. On Berlin's account, it is "simply the area within which a [person] can act unobstructed by others". 122 While this is a simple idea, Berlin's notion of positive freedom is more complex. In order to enjoy positive freedom, we must have the capacities and the goods necessary in order to live a fulfilling (e.g. autonomous) life. ${ }^{123}$ This means that we are free when we are not deflected from the pursuit of a fulfilling life by irrational impulses and when we have, among other things, access to adequate education and health care. But positive freedom, on Berlin's

114 RR, p. 30 (3.6) (on Hobbes's conception of freedom). See also RR, p. 12 (1.11) (on Britain's “proud traditions of liberty").

115 See nn. 41-3, above, and associated text. See also Discrimination Law Review, n. 93 above, p. 8 (on "[o]ur vision of a society in which there is opportunity for all and responsibility from all').

116 See G J Postema, Bentham and the Common Law Tradition (Oxford: Clarendon Press 1986), p. 42 (discussing the idea of a personal virtue of justice as elaborated by Aquinas).

117 See n. 35 above and associated text.

118 Oakeshott, On History, n. 105 above, p. 182.

119 I Berlin, Four Essays on Liberty (Oxford: OUP 1969), ch. 3, especially p. 121 (where Berlin states that he uses the words "liberty" and "freedom" interchangeably).

120 Ibid., pp. 121-34.

121 Ibid., p. 123 , note 2 .

122 Ibid., p. 122.

123 Ibid., pp. liii-lix and 131-4. On the account offered by James Griffin, the value central to positive freedom is "being a normative agent, a self-creator". This means that "value resides not simply in one's having the undeveloped, unused capacities for autonomy . . . but also in exercising them”. Moreover, it entails that we have a human right to minimum provision (including health care and education). See Griffin, On Human Rights, n. 46 above, p. 181. 
account, discloses a further dimension about which he is deeply uneasy. This is the doctrine of the "true" self. This doctrine draws a distinction between the empirical self and a true or ideal self. ${ }^{124}$ The empirical self may be a benighted individual who pursues a course through life that does not serve his or her interests. ${ }^{125}$ By contrast, the true self makes sound choices and flourishes. ${ }^{126}$ Having introduced us to the idea of the true self, Berlin argues that, in those states where it informs the thinking of government, it encourages authoritarianism. ${ }^{127}$ For government seeks to implement plans that will close the gap between (more or less) misguided empirical selves and the ideal self that it posits. ${ }^{128}$

Berlin's two conceptions of liberty or freedom clearly have relevance to the agenda that Rights and Responsibilities is supposed to play a part in advancing. Both negative liberty (e.g. freedom from interference with expressive activity) and positive freedom (claim-rights to educational and health care-related goods) feature in the body of thought that New Labour is seeking to refine. But the latter occupies a more prominent place in the minds of those who seek to shape the New Labour project. ${ }^{129}$ In Rights and Responsibilities, we see this in the emphasis the authors place on establishing conditions in which people can "thrive", "flourish", "develop", and enjoy "wellbeing". 130 Moreover, we can find in Rights and Responsibilities intimations of the doctrine of the true self that Berlin associates with governmental authoritarianism. As we have noted, the authors identify the perceived problem of "selfish individualism" (associated with the assertion of rights) as one of their primary concerns. ${ }^{131}$ They also state that one of their aims is to identify ways in which to foster a more "harmonious" society. ${ }^{132}$ When we set these points alongside one another, the picture emerges of rather self-absorbed individuals who act in ways that compromise their relations with others and (as a consequence) damage the wider social environment. This hardly sounds like a fulfilling basis on which to journey through life. But Rights and Responsibilities points the way to a more adequate set of practical relations. It does this by arguing that those who see rights through "a prism of selfish individualism" would benefit from having "a better understanding" of their entitlements. ${ }^{133}$ For they would, on acquiring this understanding, be able to enter into "peaceful and harmonious" relations with those around them. ${ }^{134}$ We might see this feature of Rights and Responsibilities as having to do with closing the gap between a self-subverting empirical self and an ideal self who, in taking proper account of others' interests, secures his or her own. If this analysis is broadly correct, then we can ascribe to the authors of Rights and Responsibilities a perfectionist agenda. This is because they want to establish a body of law that will prompt those

124 Berlin, Four Essays, n. 119 above, pp. 132-3.

125 Ibid., p. 133.

126 Ibid., p. 132.

127 Ibid., pp. 132-3.

128 Ibid. See also I Berlin, Freedom and its Betrayal: Six enemies of human liberty, H Hardy (ed.) (London: Pimlico 2003), p. 47.

129 See A Giddens, Third Way, n. 37 above, pp. 44 and 66. See also J Purnell, "New Labour became too much of a sect", The Guardian, 20 July 2009, p. 26 (arguing for "equality of capability", which involves "giving everyone the power to pursue their goals"), and S Driver and L Martell, New Labour: Politics after Thatcherism (Cambridge: Polity Press 1998), p. 105 (on New Labour's commitment to the more equal distribution of "life chances" in pursuit of “endowment egalitarianism”). Cf. J Daley, "You can 'aspire', but don't you dare achieve”, The Sunday Telegraph, 3 January 2010, p. 18.

130 RR, p. 21 (2.35).

131 RR, p. 17 (2.18).

132 RR, p. 14 (2.5).

133 RR, p. 17 (2.18).

134 RR, p. 18 (2.23). 
regulated by it to conduct themselves in ways that government considers good. ${ }^{135}$ This would not come as a surprise to Berlin. For he argues that, when government embraces the idea of positive freedom and the associated doctrine of the true self, the usual upshot is a reduction in individual freedom of action. ${ }^{136}$

Just as Berlin's distinction between negative and positive freedom is relevant to our concerns, so too is his account of values. He tells us that prominent strands of Western political philosophy have long given expression to the "dream" of "a perfect society". 137 He adds that those who seek to make this dream a reality assume that wise rulers can harmonise all sources of positive value. Berlin regards this was of thinking as utopian and has no truck with it. ${ }^{138}$ This is because sources of positive value may be incommensurable and/or uncombinable. ${ }^{139}$ The problem of incommensurability arises in circumstances where we cannot rank two or more values on a common scale. ${ }^{140}$ Uncombinability afflicts us in situations where we can only accommodate one value (e.g. security) by excluding another (e.g. freedom of action). ${ }^{141}$ In light of these points, Berlin draws some conclusions that should bring up short those who harbour hopes of Utopia. Because of the problem of incommensurability, those who govern a society necessarily have to make choices that they cannot identify as optimal. They will also have to pay for some good things in the coin of other good things. This is because they cannot escape the choices that uncombinability forces upon them.

Part of Berlin's purpose in offering this analysis of values is deflationary. ${ }^{142}$ He seeks to discourage the large ambitions that we associate with utopianism. ${ }^{143}$ But other strands of his analysis are more upbeat. Berlin argues that societies can respond to the problems thrown up by uncombinability and/or incommensurability by accommodating the relevant values in ways that give expression to "the general pattern of life" in which their members believe. ${ }^{144} \mathrm{He}$ also emphasises that the choices that concern him have to do with

135 Perfectionism gives expression to the view that we should organise practical life in ways that foster human potentialities and excellences. See W Kymlicka, Contemporary Political Philosophy: An introduction 2nd edn (Oxford: OUP 2002), p. 190. See also Eleftheriadis, "On rights", n. 9 above, p. 34 (arguing that Rights and Responsibilities is "very ambitious" since "[i]t is about what is the right thing to do"), and D Lawson, "Look out - Harriet's on a crazy crusade", The Sunday Times, 7 February 2010, p. 20 (arguing that "some of [New Labour's] leading figures have held firm to the view that it is possible through the enforcement powers of the state to improve society's moral character").

136 Crowder, Isaiah Berlin, n. 73 above, ch. 3.

137 I Berlin, The Crooked Timber of Humanity: Chapters in the history of ideas (London: Pimlico 2003), p. 20.

138 Ibid., p. 65. On this point, Berlin's thinking bears obvious similarities to that of Lev Shestov, a philosopher he greatly admired. According to Shestov, "[t] he idea of total unity", in practical matters, "is an absolutely false idea”. See L Shestov, Athens and Jerusalem (New York: Simon \& Schuster 1968), p. 431.

139 Berlin, Crooked Timber, n. 137 above, pp. 55 (on incommensurability) and 57 (on "irreducible incompatibility"). See also M Ignatieff, Isaiah Berlin: A life (New York: Metropolitan Books 1998), pp. 227-9.

140 Raz, Morality, n. 52 above, p. 329.

141 J Gray, Post-Liberalism: Studies in political thought (London: Routledge 1993), p. 301. See also I Berlin, The Proper Study of Mankind: An anthology of essays, H Hardy and R Hausheer (eds) (London: Pimlico 1998), p. 11 (noting that "[s]ome among the Great Goods cannot live together").

142 On occasion, Berlin described his (deflationary) ambition rather differently. He saw himself as giving "dreary" advice and as offering a "dull solution" to the practical problems with which humankind must wrestle. See Gray, Gray's Anatomy, n. 5 above, p. 104.

143 Crowder, Isaiah Berlin, n. 73 above, p. 4

144 Berlin, Four Essays, n. 119 above, p. lv. See also Berlin, Crooked Timber, n. 137 above, p. 18 (identifying "the forms of life of the society to which one belongs" as a typically eligible starting point for practical reflection and activity). 
"objective" values: that is values that serve genuine human interests. ${ }^{145}$ In light of these points, Berlin emerges as a pluralist who accepts that we can pursue ends that serve abiding human interests in a range of defensible ways. ${ }^{146}$

Berlin's analysis of values provides a basis on which to bring out a source of tension in Rights and Responsibilities. The authors tell us that government seeks to foster "a peaceful and harmonious society". ${ }^{147}$ But they also recognise that tensions arise when individuals exercise their rights in ways that have an adverse impact on others. We see this when, for example, the authors tell us that "an unbridled focus on our own . . rights . . . risks overtaking... respect for others". ${ }^{148}$ Berlin focuses on tensions of this sort to point up the difficulties faced by those who seek to establish a just accommodation of interests. ${ }^{149}$ Thus, we find him contemplating "the human world as a battle of . . . ceaselessly conflicting wills". ${ }^{150}$ Berlin adds that, if we take this view, we must accept that it is "incompatible" with "the very concept of Utopia" (understood as "the notion of a harmonious solution to the problems of mankind"). ${ }^{151}$

We find very little like this in Rights and Responsibilities; rather, the authors (as we have noted) refer repeatedly to the possibility of "balancing" competing considerations and contemplate the possibility of a "harmonious" society. ${ }^{152}$ Moreover, they identify a means by which to balance interests where they collide. This is the proportionality principle. ${ }^{153}$ But when we consider the sort of uses to which decision-makers can put this principle, it quickly becomes apparent that it is not an instrument for use in a literal balancing exercise. Those who use the proportionality principle do not weigh competing interests on a set of scales. Instead, they use it as a means by which to sharpen their awareness of a number of considerations that they address in a sequential order (rights, countervailing considerations and the proportionality principle's requirements). ${ }^{154}$ In going about their business in this way they are able to reflect on the question as to how they might (so far as they can) accommodate values that are uncombinable and often incommensurable. Consider freedom of expression and the threats that it may pose to the interests of others. When free expression clashes with the interests of those who live in a particular community, we cannot simultaneously prioritise both concerns. Thus, we find ourselves confronted with the problem of uncombinability. Suppose further that we attach priority to the qualified right to free expression protected by Article 10 of the ECHR. We can override the expressionrelated interests protected by this right where countervailing considerations are suitably significant. This response to the problem of uncombinability may give rise to a clash

145 Berlin, Crooked Timber, n. 137 above, pp. 11 and 80.

146 Crowder, Isaiah Berlin, n. 73 above, pp. 190-1.

147 RR, p. 14 (2.5).

148 RR, p. 17 (2.17).

149 Berlin, Four Essays, n. 119 above, pp. 123-4.

150 Berlin, Crooked Timber, n. 137 above, p. 44.

151 Ibid.

152 See ns 29 and 54 above and associated text. On two occasions the authors fleetingly sound a note reminiscent of Berlin: the first when they recognise that "individual and societal interests collide" (RR, p. 31 (3.9)) and the second when they mention "trade-offs" between principles relevant to "[1]iving within environmental limits" (RR, p. 50 (3.82)).

153 RR, p. 9, stating that "a balancing framework" involves proportionality.

154 See R v Butler (1992) 89 DLR (4th) 449 (Supreme Court of Canada), 498-9, per Gonthier J (noting that judges must sharpen their awareness of arguments in the field when deciding whether matters of pressing and substantial concern meet the proportionality principle's requirements and provide a basis on which to override fundamental rights). See also B Chapman, "Law, incommensurability, and conceptually sequenced argument" (1998) 146 University of Pennsylvania Law Review 1487, at 1507 (on the “ordered relevance" of "rights and welfare"). 
between incommensurable values. Certainly, this is the case if we assume that free expression is intrinsically valuable and that the countervailing concerns we are considering have to do with the harmful effects of expressive activity. For this is a clash between two types of moral impulse: deontological impulses (that ascribe intrinsic value to certain interests, goods and states of affairs) and consequentialist impulses (that ascribe value on the basis of outcomes). ${ }^{155}$ When these two types of impulse clash, it is far from obvious as to how we should rank them. Thus, the problem of incommensurability arises. ${ }^{156}$ In such circumstances, the term "balancing" obscures rather than explains the nature of the task judges and other public officials undertake.

While being vulnerable to this sort of criticism, Rights and Responsibilities exhibits a feature that intersects with Berlin's thinking. As we have noted, Berlin argues that societies can respond to the problems thrown up by uncombinability and/or incommensurability by accommodating the relevant values in ways that give expression to "the general pattern of life" in which their members believe. ${ }^{157}$ The authors of Rights and Responsibilities do not address the problems of uncombinability and incommensurability in terms. However, they do state that the government seeks (when advancing its responsibilities-related agenda) to capture and give more adequate expression to the form of life that would be affected by the reform it contemplates. ${ }^{158}$ Moreover, the authors place emphasis on the government's wish (when giving greater "resonance" to responsibilities) to make a "symbolic statement" that would reflect "broad aspirations" in the culture of which it would be a part. ${ }^{159}$ This suggests a commitment to elaborating "the general pattern of life in which we believe" (to use Berlin's phrase).

If we place this interpretation on Rights and Responsibilities, we can view it in a charitable light. It constitutes an effort to elaborate or refine an existing and long-standing commitment to the egalitarian philosophy of government. Likewise, it bespeaks a commitment on the government's part to the pursuit of a realistic Utopia. But the form of life in which these aspirations have grown up exhibits a richness that the authors of Rights and Responsibilities fail to capture adequately. When we scrutinise it carefully, we find that commitments to both enterprise and civil association (as described by Oakeshott) are features of this form of life. ${ }^{160}$ Given the different levels of emphasis these models of human association place on the individual, they stand in a relationship of tension. The authors of Rights and Responsibilities do not bring out this source of tension. This is because they conceive of the society they describe as an enterprise association. ${ }^{161}$ The government's insensitivity to the source of tension that we are considering would not come as a surprise to Oakeshott. He argued that those who seek to capture the main elements of a form of life can only hope to offer an abridgement. ${ }^{162} \mathrm{He}$ also described abridgements of this sort

155 On deontology and consequentialism, see S Blackburn, The Oxford Dictionary of Philosophy (Oxford: OUP 1994), pp. 67, 100 and 206.

156 T Nagel, Mortal Questions (Cambridge: CUP 1979), p. 129.

157 See n. 144 above and associated text.

158 RR, p. 32 (3.13) (on the relationship between Rights and Responsibilities, New Labour's other human rightsrelated initiatives and "national culture"). See also RR, p. 28 (2.66) (on the agenda set out in Rights and Responsibilities as a means by which to "foster our sense of shared values").

159 RR, pp. 51 (4.3) and 53 (4.11).

160 See Oakeshott, On History, n. 105 above, chs 2 and 3. See also Wilson, What Price Liberty?, n. 80 above, p. 227.

161 See Governance of Britain, n 66 above, p. 5, "Foreword" (where Gordon Brown and Jack Straw identify the reform agenda they are contemplating as having to do with the pursuit of a "shared national purpose").

162 Franco, Michael Oakeshott, n. 107 above, pp. 13 and 82-97. 
as amounting to an "ideology". 163 But this sinister sounding word (which refers, inter alia, to "systematically distorted communication") may not capture the weaknesses that Rights and Responsibilities exhibits. ${ }^{164}$ While the authors fail to recognise that two models of human association inform the cultural context that they aim to shape while also reading relevant history anachronistically, we should not assume that this makes them ideologists. It seems equally plausible to suggest that they have raked over the recent and more distant past in a way that calls to mind a clumsily executed but well-intentioned school project.

\section{Conclusions}

On the charitable interpretation offered in this essay, Rights and Responsibilities gives expression to a commitment, on the part of government, to the pursuit of a realistic Utopia in Rawls's sense. New Labour's aim, on this analysis, is to probe the bounds of political possibility. Thus, we find the authors of Rights and Responsibilities identifying a greater emphasis on responsibilities (as a counterweight to rights) as a means by which to establish a more harmonious accommodation of interests. As used here, the term "harmonious" has to do with distributive justice. This becomes clear when we recognise that the agenda of which Rights and Responsibilities is a part encompasses a wider range of goods than human rights and responsibilities. Among other things, it embraces welfare provision and public goods (e.g. security as promoted by the operation of the criminal justice system). Government regards these goods (as an ensemble) as means by which to approximate a just end-state more adequately. ${ }^{165}$

In this ambitious agenda, we might detect governmental hubris of the sort that drew criticism from Hayek. For government assumes that it has sufficient knowledge and capacity to pursue an end-state in which human rights, responsibilities, welfare provision and the public goods it seeks to foster form a harmonious whole. This is an outlook that suggests the pursuit not of a realistic Utopia but, rather, of Utopia in the strong (or optimal) sense. This would not be altogether surprising. The New Labour administrations of Tony Blair and Gordon Brown have gestured in the direction of practical arrangements that secure the interests of all relevant persons and resolve enduring sources of practical difficulty. We see this in the Third Way as propounded by Blair (which promised to resolve long-standing conflict between the left and the right in politics). ${ }^{166}$ Likewise, we see it in a recent White Paper that bears the imprint of Gordon Brown. In Building Britain's Future, the Prime Minister declares that "strong, active government" can establish a "fair balance" of interests by drawing on "the best British values". 167

While we can use the term "Utopia" to suggest naïveté on the part of those who engage in progressive politics, it has (when used as Rawls uses it) some plausibility in the British context. For Britain's history (over many centuries) discloses a commitment on the part of those who have engaged in politico-legal life to explore the bounds of possibility

163 A Sullivan, Intimations Pursued: The voice of practice in the conversation of Michael Oakeshott (Exeter: ImprintAcademic 2007), pp. 63-7.

164 On ideology, see T Eagelton, Ideology (London: Verso 1991), ch. 1.

165 The New Labour administration is far from alone in identifying human rights as part of a wider (justiceoriented) ensemble of goods. On the analysis offered by James Griffin, we can trace this view back at least as far as the Universal Declaration on Human Rights. See Griffin, On Human Rights, n. 46 above, pp. 186-7.

166 A. Giddens, Third Way, n. 37 above, pp. 37-46. See also R Mullender, "Theorizing the third way: qualified consequentialism, the proportionality principle, and the new social democracy" (2000) 27 Journal of Law and Society 493, 495-500.

167 Building Britain's Future Cm 7654 (Kew: Office of Public Sector Information 2009), p. 7, "Foreword” (emphasis added). In using "best" the Prime Minister gives expression to the assumption that all relevant values are commensurable. 
(with the aim of bringing about reforms that have been egalitarian in thrust). We see this in, for example, the development of the democratic principle and more particularly in the extension of the franchise. Likewise, we see it in the development of the welfare state and in New Labour's commitment to the protection of human rights. Moreover, we can situate these (and many other such developments) in a context that extends beyond Britain. For these developments are expressions of commitment to the egalitarian philosophy of government.

Given the many successes this philosophy has enjoyed over an extended period of time, it seems entirely appropriate that contemporary politicians should ponder the question as to how they might refine existing institutions and practices. The great success of the egalitarian philosophy of government goes some way towards explaining why those who embrace it may, on occasion, be tempted to pursue not a realistic Utopia but, rather, an optimal end-state. To the extent that this ambition informs Rights and Responsibilities, the contributions to political philosophy made by Michael Oakeshott and Isaiah Berlin provide grounds on which to subject it to critique. Oakeshott enables us to gain analytic purchase on the model of human association that informs New Labour's thinking and that finds expression in its policy agenda. It is an enterprise association within which the members of society strive to pursue (and ultimately maintain) a just end-state. While this model has many attractions (e.g. a strong commitment to distributive justice), it poses, on Oakeshott's analysis, a threat to the notion of individualism. Berlin enables us to press the analysis further by giving us, inter alia, concepts (e.g. uncombinability and incommensurability) that throw light on the difficulties involved in justly accommodating the interests of all members of society.

Finally, we have grounds for thinking that the authors of Rights and Responsibilities offer an analysis that, if used as a guide to action, would abridge the tradition of which it is a part. While we have used Oakeshott to bring this point out, Kundera has reflected on it in uncommonly powerful terms. He tells us that those who pursue an egalitarian political agenda are apt to conceive of themselves as engaged in a "grand march". ${ }^{68} \mathrm{He}$ adds that they see themselves as leading the way to a harmonious end-state that he describes as a "smiling brotherhood". 169 To the extent that Kundera captures the view that those who lead this march have of those they seek to benefit, we have reason to be uneasy. They assume that the people for whom they write a social script will happily read their lines on cue. But the tradition out of which the egalitarian philosophy of government has grown also recognises that people are apt to be awkward and that their interests clash. ${ }^{170}$ While Kundera and the other writers on whom we have drawn dwell on some or all of these points, the authors of Rights and Responsibilities do not. Instead, they invoke "responsibilities" as a basis on which to establish harmony. They seem to have in mind something more than the mutual consistency (or compossibility) of rights. ${ }^{171}$ Instead, they appear to contemplate a state of affairs in which people cultivate dispositions that will make the end-state envisioned by ministers an enduring reality. If this is the case, Rights and Responsibilities seems to go beyond the compossibility of rights and to contemplate the compossibility of

168 See Governance of Britain, n. 66 above, p. 5, "Foreword" (where Gordon Brown and Jack Straw state that "we need to begin the journey towards a new constitutional settlement"). Cf. Building Britain's Future, n. 167 above, where the Prime Minister identifies the government as "driven" by "the best of British values".

169 See also Oakeshott, On Human Conduct, n. 105 above (identifying the leaders of an enterprise association as holding out "the promise of salvation" to their "followers").

170 Wilson, What Price Liberty?, n. 80 above, p. 52, and Berlin, Four Essays, n. 119 above, p. 124.

171 On the compossibility of rights, see H Steiner, An Essay on Rights (Oxford: Blackwell 1994), pp. $2-3$. 
persons. ${ }^{172}$ Assuming that this is broadly correct, we have a basis on which to conclude that New Labour is pursuing something more ambitious than a realistic Utopia. For (as Rawls tells us) those who probe the limits of practicable political possibility should take people as they are: complex creatures who make unlikely candidates for inclusion in a smiling brotherhood. ${ }^{173}$

172 We might see Berlin as having the compossibility of persons in mind when he observes that the "antiUtopias" of Huxley, Orwell and Zamyatin "paint a horrifying picture of a frictionless society in which differences between human beings are, as far as possible, eliminated". See Berlin, Crooked Timber, n. 137 above, p. 45. See also Oakeshott, On Human Conduct, n. 105 above, p. 278 (on "a state from which the last vestiges of civil association had been removed, a solidarité commune in which there was no distinction of persons and from which no one was exempt") and Eleftheriadis, "On rights", n. 9 above, p. 41 (arguing that the authors of Rights and Responsibilities identify a new Bill of Rights and Responsibilities as necessary in order properly to "calibrate our practice of human rights" by treating "[ $\mathrm{t}]$ he motives and personal attitudes of the persons exercising them" as relevant to the "scope" of their entitlements (emphasis added)). While the point cannot be pursued in detail here, to regard people as compossible may be to make a category mistake. Rights are artefacts. Hence, we may specify them in mutually consistent ways. But people are (sometimes refractory) agents who may be disinclined to act in accordance with our plans (even when those plans have to do with establishing a distributively just model of human association). Hence, talk of the compossibility of persons leads on to the tricky topic of human nature. Here, New Labour's use, among other things, of the locution "ordinary people" does not suggest a particularly flattering view of those whose interests it seeks to secure and/or promote. See, for example, Review of the Implementation of the Human Rights Act: Myths and misconceptions (London: Department of Constitutional Affairs 2006), p. 42 (on "the benefits which the Human Rights Act has given ordinary people"). Cf. D Kennedy, “The international human rights movement: part of the problem?” (2002) 15 Harvard Human Rights Journal 101, pp. 113 and 116-17 (arguing that the post-World War Two human rights movement has encouraged an approach to governance that places the state at "the center of [its] emancipatory promise" and that may stultify those whose interests it seeks to secure), and R M Unger, What Should Legal Analysis Become? (London: Verso 1996), p. 185 (arguing that "there is more in us . . than there is in the institutional ... worlds we make and inhabit").

173 Rawls, The Law of Peoples, n. 82, above, pp. 12-13. 